doi:10.29285/actapinteriana.2018.4.21

\title{
Mit is játsszunk ma? Was wollen wir heute spielen? ${ }^{1}$
}

\author{
Peter Lippert $^{2}$ \\ Fordította: Paulik Péter, \\ A szöveget gondozta és sajtó alá rendezte: Bagyinszki Péter Ágoston OFM ${ }^{\mathrm{a}}$ \\ ${ }^{a}$ Sapientia Szerzetesi Hittudományi Főiskola, 1052 Budapest, Piarista köz 1. \\ bagyinszki.agoston@sapientia.hu
}

Lippert, P. (2018): Mit is játsszunk ma? Was wollen wir heute spielen? Fordította: Paulik Péter; A szöveget gondozta és sajtó alá rendezte: Bagyinszki Péter Ágoston OFM. Acta Pintériana, 4, 21-26.

\begin{abstract}
Die Titelfrage mag auf den ersten Blick wie eine Kinderfrage erscheinen, da wir unsere Tage mit vorgegebenen und vorgeschriebenen Aufgaben anfüllen. Wir fühlen uns, als ob uns der Luxus des Spielens gar nicht erlaubt sein dürfte. Worauf kommt es eigentlich an? Was soll der Mensch tun, damit es sinnvoll und wertvoll ist, sein Tun? Nach Lipperts Antwort wäre unser Tun der Mühe wert, wenn es eine Nachbildung und Fortsetzung der göttlichen Arbeit, der Weisheit Gottes darstellen würde. Ein solches Tun wäre dann auch ein schöpferisches Tun und ein Wohltun. Man würde von dem Ergebnis unseres Tuns sagen können, was Gott selbst von den Werken seiner Hände sagen durfte: Siehe, sie waren gut, sie waren sehr gut. Es müsste ein schönes Schaffen und ein frohes Arbeiten sein, wenn wir zu all dem, was da ist, etwas hinzutun dürften. Diese Weisheit Gottes ist doch nach der Bezeugung der Heiligen Schrift eine spielende! Die Titelfrage sei also nicht kindisch, sondern kindlich. Spiel ist eben keine Trägheit, es ist vielmehr höchste Kraft. Lipperts Essay aus den dreissiger Jahren des 20. Jahrhunderts ermutigt uns, unser ganzes Leben einfach gewähren zu lassen trotz aller Last, Not und Leid, durch die wir uns ebenfalls Gott nähern - und es wie ein grosses Spiel zu erleben.
\end{abstract}

Ne orroljatok meg rám tüstént, barátaim, hogy e gyermeki kérdéssel állok elétek! Szinte hallom, ahogy megütközve visszakérdeztek: „Hát gyermek vagyok én? Van is nekem időm vagy akár csak kedvem játszani! Számít-e egyáltalán, hogy mit akarok? Mikor tehetem meg, hogy olyan békés, várakozás teli kérdéssel kezdjem akár csak egyetlen napomat is, mint a gyermekek?” Ök, ha jól kialudták magukat és túl vannak a bőséges reggelin, élvezettel tủnődhetnek el azon:

$$
\text { „Mit is játsszunk ma?” }
$$

Ó, boldog gyermekévek!

\footnotetext{
${ }^{1}$ A fordítás alapjául szolgáló mú: P. LIPPERT (1936): Was wollen wir heute spielen?. Stimmen der Zeit, 130: 1-6. A cikk megjelent még in uő (1936): Einsam und Gemeinsam. Herder, Freiburg. (A szerzői jogok lejártak.) A cikk német nyelven elektronikusan elérhetö: https://www.ojc.de/salzkorn/2004/kindschaft-kind-gottes/gottesplan-spielen-was-er-vor-hat

2 Peter Lippert SJ (1879-1936) a múltszázad első felében lelkipásztori tevékenysége, rádióban elhangzott prédikációi, valamint a Die Seele és a Stimmen der Zeit címủ folyóiratokban megjelent cikkei által vált ismertté. Több mint 30 könyve jelent meg. Müvei, amelyek frissességükkel még napjainkban is megszólítanak minket, karizmatikus embertől érkező személyes üzenetként hatnak, és így maradandó értéket képviselnek.
} 
Igen, barátaim, tudom, ennyire nem jó a helyzet, már rég nem. Hiszen napjaink óráról órára, percről percre elöre be vannak táblázva. A munkahelyi taposómalom, a család, a barátok és ismerősök, állampolgári kötelességeink, testi szükségleteink - egy láthatatlan úr e hüséges szolgái - mind végeláthatatlanul gondoskodnak számunkra az elvégzendő feladatokról. Egyik nap követi a másikat, és nincs megállás reggeltől estig. Már az is nagy eredmény, ha a hétvégén félénken feltesszük magunknak a kérdést: vajon kijutok ma végre a szabadba, a zöldbe, a tóhoz vagy a hegyekbe?

Így tehát valószínüleg el sem jutunk addig, hogy felvessük azt a mélyenszántó kérdést, hogy voltaképpen mi az, ami igazán fontos? Mit kell tennie az embernek ahhoz, hogy tettei értelmesek és értékesek legyenek? Ha egyszer néhány évre teljes szabadságot kapnánk, s magunk választhatnánk meg és rendezhetnénk el teendőinket, biztos nem töprengenénk túl sokat; mindannyian kapásból tudnánk, melyik kedvenc munkánkkal vagy kedvtelésünkkel töltenénk ezeket a szabad éveket. Vannak, akik könyvet írnának vagy festenének, mások beültetnék a kertet kis házikójuk körül, valahol kinn a zöldben; megint mások valami sürgető és nélkülözhetetlen találmánnyal állnának elö, és lenne, aki a sztratoszférát utazná be, vagy hegyet mászna valahol a világban, ahol még senki se járt; de lennének olyanok is, akik rendbe szednék végre a világgazdaságot. És én, igen, barátaim, őszintén bevallom nektek: nem csinálnék semmit, legalábbis nem szőnék terveket. Hiszen akkor lázas igyekezettel kiszínezett szabad éveinkre ismét teljesen kötve lennénk. Pedig ez a néhány év talán még arra sem lenne elegendő, hogy sok felismerés és csetlés-botlás után rájöjjünk: mindez még mindig nem az igazi, még ez sem nyújt teljes megelégedettséget. Talán el se jutnánk addig a - már említett mélyreható és nehéz kérdésig, hogy tetteink voltaképpen mitől helyesek, felszabadítóak és helyénvalók? Mit tegyen az ember, ha méltósága, belső életérzése, lelki vágyai szerint akar élni? Mi az, amiért végső soron érdemes fáradozni?

Azt hiszem, barátaim, a szabad éveinkre látszólag szabadon választott tevékenységünkkel szinte mindannyian holtvágányra jutnánk. Nagy lendülettel vágnánk bele dédelgetett terveink megvalósításába, de hamar belefáradnánk. Elkönyvelhetnénk némi sikert és sok kudarcot, de addig a gondolatig nem jutnánk el, ami miatt voltaképpen ezt az egészet akartuk. Nem gondolkodnánk el rajta, hiszen miért épp az ne lenne valóban szabad, amit szabadon választottunk. Márpedig ez is valamiféle meghatározottság lenne - persze nem külső hatalomtól, körülménytől, szervezettől való, hanem belülről, valamilyen titokzatos késztetésből fakadó. Valamiféle belső elhivatottság, sőt szelíd kényszer, amely bennünk van ugyan, de eredete mégis rajtunk kívül áll. Olyan adottság, ami a mindenség titokzatos mélyéből ered, és amit Teremtő Istenünk hallhatatlan igékkel a bensőnkbe írt. El tudtok képzelni szabadabb, boldogabb embereket azoknál a szerencséseknél, akiknek - egy roppant belső parancs szólítása nyomán - minden lehetőségük megvan arra, hogy engedelmeskedjenek e parancsnak? Ök azok, akik késztetést éreznek arra, hogy müalkotásokat hozzanak létre; kifürkésszenek valami távoli, ragyogó égitestet, a világ egy felfedezetlen részét a mérhetetlen messzeségben, vagy eleget tegyenek valamilyen megbízásnak az egész emberiség vagy csupán csak népük javára. Ezek az emberek hordozzák magukban azt a leküzdhetetlen vágyat, hogy ismeretlen orchideára leljenek a délamerikai őserdőkben, vagy expedíciót indítsanak egy másik bolygóra. Nem hagyja őket nyugodni egy bizonyos számelméleti probléma, vagy mindenáron úgy érzik, föl kell kutatniuk egy elveszett kéziratot. Bármiről legyen is szó, a lényeg, hogy a belső parancsnak és a véletlenek külső összejátszásának köszönhetően egész életükön át annak élhetnek, amire vágynak. El tudtok-e képzelni náluk boldogabb embereket, hiszen ők látszólag annyira szabadok, annyira gondtalanok.

Pedig ők sem választják meg szabadon, amit tesznek; valaki már választott számukra. Ez az a kiirthatatlan kutató ösztön, amely ott él az emberiségben, és amely az egyes embert újra és újra hatalmába keríti és megigézi. Még ha a nagy többség inkább üldögél is otthon békésen, mindig lesznek olyan hóbortos őrültek, akik úgy érzik, hogy valami őserdei virágcsoda kedvéért kockára kell tenniük életüket. Ha a nagy többség nem is kíváncsi többre a helyi lap híreinél, azért mindig lesznek 
olyanok, akiket nem hagy nyugodni a vágy, hogy utánajárjanak, hogyan él egy kis rovar, vagy miként állították össze holdnaptárukat a régi babiloniak.

Mindennek ellenére még sincs értelme annak, hogy e néhány kiválasztott tökéletesnek tủnő szabadsága láttán - akik ajándékul kapták ezt a szabadságot - föltegyük a kérdést: tevékenységük értelmes és értékes-e, megéri-e a fáradságot? Mert amit tesznek, az éppenséggel bizonyos értelemben „szükségszerü”. Kell, hogy az emberiség néhány tagja ily különös és talán pont ezért ily fenségesen és lélegzetelállítóan szép foglalatosságoknak szentelje magát, hiszen az emberiség géniusza, a tudás, az alkotás, a merész vállalkozás, vagyis az élet géniusza egyszerủen erre készteti őket. Az ember legtöbbször el se jut odáig, hogy elgondolkodjon azon, vajon szükségszerü volt-e a jégkorszaki barlangok mélyéről kiköltözni a mai nagyvárosok felhőkarcolóiba. Ez volt ugyanis az az út, amelyen az emberiség vezettetett, mi több, űzetett. Ez az üzöttség azonban évröl évre sürgetőbbé, feltartóztathatatlanul viharosabbá és fájdalmasabbá válik. Egyre több olyan ember él és cselekszik a világban, akik révén felgyorsul a fejlődés menete, akik felebarátaikat, népüket $\mathrm{s}$ végül az egész emberiséget szinte erőszakkal taszigálják előre az ismeretlen új célok felé vezető úton. Vajon miért?

Látod - mondjátok ti erre, barátaim -, milyen tévútra vitt gyermeki kérdésed, hogy mit is játsszunk ma? Egyikünknek sem lett saját tetszésére bízva, hogy megválassza, amit tesz, még a legjobbaknak, a kiválasztottaknak sem. Minden elöre adva van számunkra. Igen, barátaim, igazat kell adnom nektek, és ezt némileg szégyenkezve mondom. Hadd módosítsam tehát egy kicsit, mindössze egy apró grammatikai átalakítással a kérdésemet: mit is játszanánk, ha játszhatnánk? Mert azt ugye csak nem tagadjátok meg tőlem, hogy távoli, szép jelenésként ott lebegjen a szemünk előtt valami olyan tevékenység, amely mindenképpen megéri az erőfeszítést, a fáradságot még azok számára is, akik már megválaszolták maguknak a nagy kérdést: voltaképpen mi is az, ami maradandó és tartós, igaz emberi és örök isteni érték? Hiszen már volt elég időnk és alkalmunk arra, hogy mindent kipróbáljunk - ha másként nem is, de legalább gondolatban, vagy valóságosan. És látnotok kell, hogy nem folyt szét minden a kezünkből és nem hervadt el az összes virágunk, mégiscsak vannak még vágyaink: komoly, szent vágyaink. Mindannyian szeretnénk érezni, hogy Istenünk megérint bennünket - ezt szeretnénk. Szeretnénk virágba borulni és növekedni, mint a növény, melyre rátekint sugárzó mosolyával. Szeretnénk alkalmas eszközként simulni kezébe, hogy azt tegyen velünk, amit csak akar. Igen, ezt szeretnénk. És amit az ő szelíd, de határozott érintése nyomán tennénk, ahogy a dolgokhoz nyúlnánk és amit létrehoznánk, az bizony isteni kinyilatkoztatás lenne. Ö válna láthatóvá abban, ahogy kibontakozunk, öt lehetne megérezni minden finom rezdülésünkben. Tetteink érzékelhetővé tennék Istent, meg lehetne sejteni valamit az ő szépségéből, jóságából, szabadságából és tágasságából, az ő erejéből és bizonyosságából, az ő szent akaratából és abból, ahogy nagyvonalúan kormányozza a világot, valamit az ő kitartó hüségéből és az ő kimondhatatlan irgalmasságából.

Akkor a most még csak álmainkban kibontakozó tetteink valódi teremtő tettek, valódi születést és újjászületést hordozó tettek lennének, az Isten szándéka szerinti teremtő erő és a természet nyilvánulna meg és kelne életre bennük. Tetteinkről el lehetne mondani, amit maga Isten elmondhatott kezének műveiről: látom, hogy jók, nagyon jók. Ó igen, barátaim, bárcsak minden, amihez nyúlunk, őszinte és igaz lenne, és meg is maradna annak, kacskaringók, csorbulások, torzulások nélkül! Bárcsak jól, célratörően, állhatatosan, ígéretesen csinálnánk végig mindent, amibe belefogunk, nem pedig tesséklássék, hamis és tékozló, hazug és álszent módon. Igen, bárcsak jól végeznénk mindent, amit teszünk hiszen valamit azért mindig tehetünk -, szorgosan, gondosan, alázattal, odaadóan. Bárcsak tetteink nyomán valóban rendbe jönnének a dolgok, és visszatalálnának a rendes kerékvágásba. Bárcsak a magunk munkálkodásáról is elmondhatnánk, amit Isten az övéről mond:

„Megkeresem az elveszettet, visszaterelem az elszéledtet, bekötözöm a sérültet, ápolom a beteget, a kövér és egészséges fölött meg örködöm.” (Ez 34,16) 
Így lenne egyúttal jótétemény, amit teszünk. Igen, barátaim, mondjuk csak ki őszintén: munkálkodásunkkal szeretnénk elevenebb és otthonosabb hellyé tenni a világot és annak minden szögletét. Azt szeretnénk, ha több fény lenne, ha világosabb és melegebb volna, ha több csillag ragyogna, ha a féktelen tengereket jobban meg lehetne zabolázni, a szárazföldek pedig biztonságosabbak lennének, ha élettől nyüzsögne minden a vízben, a levegőben és a mélyben, ha minden átlelkesültebb, elevenebb és értelmesebb lenne. Sőt, szeretnénk teremtő munkánk szegletkövévé tenni az embert, hogy az ember azzá legyen, aki azon a hatodik napon Isten szeme előtt lebegett: az Ő képére és hasonlatosságára teremtett emberré. Ó, mily széppé teszi az alkotást, a munkát pedig hogy megvidámítja, ha mindahhoz, ami van, hozzátehetjük a magunkét, csöppnyi létet, fénysugarat, szikrányi életet, leheletnyi lelket.

Akkor álmainkból kibontakozó tetteink Isten munkálkodását mintáznák és folytatnák tovább, aki úgy teremt, hogy „,földíszíti a mennyet”. Az isteni Bölcsességet mintáznák és folytatnák tovább, amely „erejét kifejtve elér (a világ) egyik végétöl a másikig, és a mindenséget üdvösen igazgatja” (Bölcs 8,1 ). De nézzétek, barátaim, nem tudok most magamba fojtani egy diadalmas örömkiáltást. Isten Bölcsessége játszik:

\section{„Napról napra csak bennem gyönyörködött, mindig ott játszottam a színe elött. \\ Ott játszottam az egész földkerekségen." (Péld 8,30 sk.)}

Vagyis ez végső soron számunkra is játék. Ami szépséges álomként lebeg előttünk és hívogat, ez az egészen emberi és egészen isteni tevékenység, éppenséggel olyan, mint egy játék, vagyis mégiscsak föltehetjük a kérdést:

Mit is játsszunk ma?

Ezért nem szabad felületesen úgy gondolkodnunk a játékról, mintha valami gyerekes dolog lenne. Gyermekinek valóban gyermeki; mert Isten megszemélyesített Bölcsessége, aki mintegy az ő lelki Gyermeke, szüntelenül ott játszadozik a Teremtő színe elött. De gyerekesnek nem gyerekes, mert a játék nem balgaság, hanem bölcs dolog, a Bölcsesség játssza. Ne gondoljuk tehát, hogy e játék valamiféle restség, tékozlás vagy méltatlan élvezet lenne. A játék lehet nagyon aktív, mi több megerőltető dolog is, valamiféle aszketikus, sok önuralmat, lemondást, kitartást és makacsságot követelö tevékenység. A játék épp, hogy nem restség, sokkal inkább hatalmas erőforrás. Játszani azt jelenti, hogy egészen szabad, elfogulatlan, görcsöktől mentes lelket hordozunk magunkban, és úgy vagyunk jelen a dolgainkban. Játszani azt jelenti, hogy szerető érdeklődéssel és gyermeki örömmel viszonyulunk ahhoz, amit csinálunk. A játék elengedés és engedékenység, épp úgy, ahogy a kicsinyeket hagyjuk játszani; hancúrozzanak, ahogy akarnak, akár a kiscsikó a réten. Hadd játsszanak!

De vajon tudunk-e még így játszani, ilyen oldott, ilyen szabad, ilyen örömteli módon munkálkodva? Igen, barátaim, tudunk, ha újra hagyunk teret a játéknak. Lelkünk játszótereit újra szabaddá kell tennünk. Ennek útjában áll egy s más: mindent oly szörnyen komolyan veszünk, mindenben csak a terhet, a nehézséget és a gondot látjuk; igen, játszótereink a sok gonddal vannak tele, vagy még inkább azzal, hogy sokat foglalkozunk gondjainkkal. A gyermek akkor is képes játszani, ha fáj a foga, de ha önmagát sajnálva sírni kezd, akkor már nem képes játszani. Vajon nincs-e bennünk túl sok önsajnálat beteljesületlen vágyaink miatt?

Azután zavar bennünket a játékban a határtalan „szerzési” vágyunk. Nem önmagában a betevő megszerzése az akadály, hanem az, hogy mindent meg akarunk szerezni, pénzt akarunk, mindig többet és többet. Nyugtalan kielégületlenségben élünk, bánkódunk minden még meg nem szerzett Mammon miatt, amiről azt feltételezzük, hogy kielégítheti mohó birtoklási vágyunkat. A mohó ember azonban nem képes játszani, lelkében túlteng a félelem, a szükkeblüség és a görcsös igyekezet.

Leginkább azonban saját harcunk és annak lármája zavar bennünket a játékban. A csatatér nem játszótér. Harcolnunk kell - és ezt felpanaszolhatjuk Istennek -, küzdeni kell a mindennapi betevőért, 
a puszta jogainkért, az életben maradásért, azért, hogy egy kis éltető levegőhöz jussunk, még azért a kis vidámságért és örömért is meg kell küzdenünk, amelyre annyira szükségünk van. Azt viszont mégsem hagyhatjuk, hogy ez a küzdelem kerüljön gondolataink középpontjába, életcélunkká váljon, mert akkor ez az örökös harc lesz számunkra az élet beteljesítője. Kitölti persze minden időnket, de épp úgy nem lehet az élet beteljesítője, mint ahogy a levegőben jelenlévő porról sem állítható, hogy beteljesítője lenne azoknak a szépséges tereknek, ahol a madarak és a csillagok járnak. Mindig azt hisszük, hogy nincs más lehetőségünk, mint hogy fölvegyük a kesztyüt. Pedig a küzdelem a dolgoknak csak előkészítője, velejárója és elrendezője, egyfajta gyomlálás, de nem betakarítás. Sőt gyarapodást vagy boldogulást sem jelent, hiszen mire az ember kitépi a gazt, az néhány termékeny csírát elhullatott már a földbe, és növekedésével gátolja a termés beérését.

Barátaim! Nem várhatunk addig, amíg legyőzzük az összes nehézséget. Ha addig nem örülünk az életnek, nem éneklünk himnuszokat és nem játsszuk Isten játékait, akkor el se jutunk odáig; mert mindig a nehézségeink fognak körülvenni minket. Nézzétek, mily csodálatra méltó az a szegény müvész, aki korgó gyomorral, lázasan vacogva ül kis padlásszobájában, és alkot. Nem vár arra, hogy ne éhezzen és ne fázzon. Annak ellenére, hogy a nehézségek felemésztik erejét, tartalékol valamennyit a nemes alkotómunka számára. Nem fordítja minden energiáját a nehézségek leküzdésére, még akkor sem, ha ezek mint ellenség rontanának rá, megrendítenék, s fölébe kerekednének. Ö ki akarja használni az időt - bármily rövid legyen is az - arra, ami minden küzdelemnél fontosabb: az önvédelemnél előbbrevaló alkotásra, arra, hogy meglelje magában s lejátssza az ott rejlő melódiákat.

Jöjjetek barátaim, tegyünk valami szépet, valami tiszta, elbüvölő isteni dolgot, akkor is, ha gondok szorongatnak, kínoznak és pusztítanak - noha véleményem szerint nehézségek ritkán ölnek játszadozó gyermekeket. Túl gyakran foglalkozunk feltételezett gondjainkkal, s így újabb nehézségeket okozunk magunknak. Túlságosan megkeményedett a szívünk, ádáz tekintetünk olyan félelemmel tölti el a világot, hogy a többi teremtmény nem gondol a játékra, nem jön oda hozzánk játszani, csak a harcra, önvédelemre gondol. Kevesebbet kellene beszélnünk az önmegvalósításról, sokkal inkább el kellene engednünk a dolgokat, a magunkét is, másokét is:

\section{„Hagyjátok a gyermekeket!”}

Ha folyton azzal vagyunk elfoglalva, hogy másokra kényszerítsük akaratunkat, arra már nem lesz időnk és figyelmünk, hogy hagyjuk kibontakozni a bennünk és másokban rejlő nemes energiákat. Túl elhamarkodottak, túl türelmetlenek vagyunk; még ki sem nyílt a gyümölcsfa virágja, de mi már gyümölcsöt akarunk szedni róla; még ki sem alakult valami, már meg akarjuk mondani, milyen legyen.

Lenne bizony hely és idő, ahol és amikor játszhatnánk, csak akarnunk kellene. Olykor bizony megkérdezhetnénk magunktól:

\section{Mit is játszanánk ma, ha rászánnánk magunkat?}

Lennének Isten színe elött előadható jeleneteink, csodás történeteink, nem kellene ragaszkodnunk a szomorú játékokhoz, amelyek tragikus véget érnek. Az legkevésbé múlik Istenen, hogy a történeteink mindig gyilkossággal és halállal végződnek. Ö éppen hogy vidám végkifejletet gondolt el a természet és az emberi történelem egész nagy színjátékának, és minket is olyanoknak szeretne látni, akik ilyen vidáman dalolják és játsszák az életüket. A nevetés és a tréfa biztos nincs ellenére. Pontosan az Isten munkálkodásának hasonlatosságára végzett, szimbolikus erejű emberi tevékenység lehet csak boldog és örömteli cselekvés, gyógyító és szabadító, s csak az képes erőt adni és éltetni.

De látom már, barátaim, csüggedéstek csak nem akar egészen feloldódni. S nem is oldódhat fel egészen. Mert továbbra is igaz, hogy sokat nem töprengünk azon, mit is játsszunk ma. Marad a mindennapok és a múló évek állandó robotja, amiben megragadtunk. De nézzétek, ezt is, ezt a leckét is felfoghatnánk játéknak és végezhetnénk aszerint, ha csupán szabad, elfogulatlan és vidám lélekkel 
viszonyulnánk hozzá, ha mindig jókedvűen igent mondanánk, amikor nekifogunk a ránk háruló munkának. Mert, tudjátok, az ember szabad lélekkel a kényszerüt is el tudja végezni, hiszen a kényszer sose kerekedik egészen felül: nem az övé az utolsó szó. Ha vannak is olyanok, akik egy életen át csak munkát, verítéket és szenvedést okoznak nekünk, ők is csak egy nagyobb Úrnak a piciny szolgái. Ennek a nagy Úrnak pedig nagy a szíve is. Hajóját felénk kormányozza a hullámokon, és bármivel kerüljünk is szembe, minden azt az utat egyengeti, amelyen ő közelít hozzánk. Ö játszik az evezőkkel úgy, hogy olykor ne lássuk őt a nagy hullámoktól, amelyeket kavar. Hagyjuk csak, hadd játsszon az evezőkkel és a hullámokkal, hiszen felénk tart.

Így hát ragadjuk meg mi is a magunk evezőit, és fussunk ki bátran a hullámokra, amelyek szinte teljesen elveszik a kilátást; mert nézzétek, barátaim, épp e hullámokon keresztül, és pont ezekkel az evezőkkel vezet Őhozzá az út! Még a legbalgább kényszer is valahol szabadságban végződik, és a legsötétebb elhagyatottság is csak kapu az együttlétre. ${ }^{3}$ A legérdektelenebb és legértelmetlenebb tett is olyan, mint egy híd, amelyen átmegyünk, és a legszörnyübb sors csupán fátyol, amely mögött a szépség rejlik. Ezért mindezt szabadon és hanyagul, gondtalanul és súlytalanul a kezünkbe vesszük. Nem vesszük komolyabban, mint egy játékot, amelyet az ember épp csak addig játszik, amíg van rá idő; de félvállról sem vesszük, hanem úgy, mint egy gyermek a játékát, amely kitölti napjait: komolyan és önmagát átadva neki, de mindig készen arra, hogy abbahagyja, ha felhangzik a hazahívó szó:

\section{No, most már gyere!}

Barátaim, hadd tegyem föl hát még egyszer a gyermeki kérdést - mit is játsszunk ma -, és meg is adom rá a magam válaszát. Ó, barátaim, játsszuk azt, amit Ő nekünk szánt! Hagyjuk, hadd tegye kedvére! És hagyatkozzunk rá úgy, mint amikor játszunk: derüsen, gondtalanul, szabadon és elfogulatlanul, görcsös igyekezet és kapkodás, félelem és levertség nélkül. Gyertek, játsszuk most és mindenkor azt, amit Isten juttat nekünk!

\section{Irodalom - References}

LIPPERT P. (1936): Einsam und Gemeinsam. Herder, Freiburg.

LIPPERT P. (1936): Was wollen wir heute spielen? Stimmen der Zeit, 130: 1-6.

RAHNER, H. (2013): A játszó ember, Kairosz, Budapest.

\footnotetext{
${ }^{3}$ A következő néhány mondat már megjelent magyarul, in HUGO RAHNER: A játszó ember, Kairosz, Budapest, 2013, 134. Jelen fordítás ezen a ponton a korábbi szövegváltozatot is figyelembe vette. Hugo Rahner SJ munkája - amelyet érdeklődő olvasóinknak szívből tudunk ajánlani - mélyrehatóan feltárja Peter Lippert elmélkedésének teológiai gyökérzetét és tágabb teológiai összefüggéseit, valamint a „ludikus létértelmezési kulcs" életértékét. (a szerk.)
} 